\title{
Positive association between leptin serum levels and disease activity on endoscopy in inflammatory bowel disease: A case-control study
}

\author{
FABIOLA TREJO-VAZQUEZ ${ }^{1,2}$, IDALIA GARZA-VELOZ ${ }^{1,3}$, \\ GABRIELA ALEJANDRA VILLELA-RAMIREZ ${ }^{1,3}$, YOLANDA ORTIZ-CASTRO ${ }^{1}$, \\ PANFILO MAURICIO-SAUCEDO ${ }^{1,4}$, EDITH CARDENAS-VARGAS ${ }^{1,4}$, MARIANA DIAZ-BAEZ ${ }^{2}$, \\ MIGUEL A. CID-BAEZ ${ }^{1,3}$, RODRIGO CASTANENAA-MIRANDA ${ }^{3}$, JOSE MANUEL ORTIZ-RODRIGUEZ ${ }^{3}$, \\ LUIS OCTAVIO SOLIS-SANCHEZ ${ }^{3}$ and MARGARITA L. MARTINEZ-FIERRO ${ }^{1,3}$ \\ ${ }^{1}$ Molecular Medicine Laboratory, Unidad Academica de Medicina Humana y Ciencias de la Salud, \\ Universidad Autonoma de Zacatecas 'Francisco García Salinas', Zacatecas 98160; ²Department of Gastroenterology, \\ Hospital General de Zacatecas, Instituto de Seguridad y Servicios Sociales Para Los Trabajadores del Estado; \\ ${ }^{3}$ Bioengineering Laboratory, Unidad Academica de Ingenieria Electrica, Universidad Autonoma de Zacatecas, \\ Zacatecas 98000; 'Departamento de Enseñanza e Investigación, Hospital General Zacatecas ‘Luz González Cosío’, \\ Servicios de Salud de Zacatecas, Zacatecas 98160, Mexico
}

Received September 7, 2017; Accepted November 17, 2017

DOI: $10.3892 /$ etm.2018.5835

\begin{abstract}
Inflammatory bowel disease (IBD) includes ulcerative colitis (UC), Crohn's disease (CD) and indeterminate colitis. As these subtypes of IBD display important differences in the behavior of the natural course of the disease, the identification of non-invasive markers for IBD is important. The aim of the present study was to evaluate the serum levels of 10 adipokines and their association with endoscopic activity in IBD. The 10-protein profile (C-peptide, ghrelin, gastric inhibitory polypeptide, glucagon-like peptide-1, glucagon, insulin, leptin, plasminogen activator inhibitor-1, resistin and visfatin) was evaluated using serum from 53 participants (23 UC and $11 \mathrm{CD}$ patients, as well as 19 controls) from Zacatecas (Mexico) by using the Bio-Plex Pro Human Diabetes 10-Plex Panel (Bio-Rad Laboratories, Inc.). Compared with those in the controls, leptin levels were significantly lower in patients with IBD $\left(\mathrm{P}=4.9 \times 10^{-4}\right)$. In addition, serum leptin displayed differences between groups with and without disease activity on endoscopy $(\mathrm{P}<0.001)$. Among the study population, serum
\end{abstract}

Correspondence to: Dr Margarita L. Martinez-Fierro, Molecular Medicine Laboratory, Unidad Academica de Medicina Humana y Ciencias de la Salud, Universidad Autonoma de Zacatecas 'Francisco García Salinas', Campus UAZ Siglo XXI, Edificio L-1, Km 6 Carretera Zacatecas-Guadalajara, Ejido 'La Escondida', Zacatecas 98160, Mexico

E-mail: margaritamf@uaz.edu.mx

Key words: bowel disease, leptin, adipokines, inflammation, endoscopic activity leptin levels of $<5,494 \mathrm{pg} / \mathrm{ml}$ significantly increased the odds of IBD by 12.8 -fold [odds ratio $(\mathrm{OR})=12.8,95 \%$ confidence interval $(\mathrm{CI})=3.04-53.9, \mathrm{P}=0.001]$. In addition, patients with serum leptin levels of $<2,498 \mathrm{pg} / \mathrm{ml}$ displayed 5.8 -fold greater odds of disease activity on endoscopy among the study population $(\mathrm{OR}=5.8,95 \% \mathrm{CI}=1.52-22.4, \mathrm{P}=0.013)$. No differences in the serum levels of the remaining proteins were identified between the groups. Among the study population, serum leptin was associated with an increased risk of IBD and with disease activity on endoscopy. Additional studies will be necessary to validate the use of leptin as a non-invasive biomarker of IBD severity.

\section{Introduction}

Inflammatory bowel disease (IBD) involves ulcerative colitis (UC), Crohn's disease (CD) and indeterminate colitis. These subtypes of IBD display important differences in the behavior of the natural course of the disease, including frequent remissions and exacerbations, response to treatment and complications. Early diagnosis is critical for proper treatment (1). In Mexico, in the last 10 years there has been an increase with 76 new UC cases per year, which is a dramatic increase compared with the previous decade that recorded an average of 28 cases per year, accumulating 150,000 cases in Mexico (2,3). Despite increased use of immunosuppressive therapy, the long-term risk of required intestinal resection and permanent ileostomy in CD is $\sim 80$ and $10 \%$, respectively (4). In UC patients, the risk of required colectomy is $\sim 1 \%$ per year according to population-based cohort studies in Northern Europe (5).

Remission in UC is defined as complete resolution of symptoms and endoscopic mucosal healing, whereas in $\mathrm{CD}$, a clinical remission is considered as one with a clinical 
disease activity index (CDAI) of $<150$ (6-8). In CD and UC, the early use of aggressive therapy, including the combination of thiopurines and anti-tumor necrosis factor- $\alpha$ (anti-TNF- $\alpha$ ) is considered, with the aim of achieving deep and sustained remission (9). However, certain CD patients present with localized and uncomplicated (no perforation, no stricture) disease at diagnosis. Similarly, UC may manifest without disabling symptoms, biological abnormalities or severe endoscopic lesions at diagnosis. In those patients, the early and prolonged use of immunosuppressive therapy (anti-TNF- $\alpha$ ), with its associated risk of serious infections and cancer, may not be appropriate, as the spontaneous evolution of the disease may have been benign $(10,11)$.

The risk of over-treating patients may be reduced by accurately diagnosing them with a combination of clinical and endoscopic examination, as well as detection of serological markers present in different stages of the disease, which may predict the subsequent course of IBD; however, serological biomarkers for the severity of IBD have been far lees studied in UC than in $\mathrm{CD}$, and it has been rarely applied in the clinical setting (12).

TNF- $\alpha$ is a cytokine involved in the regulation of a wide spectrum of biological processes, including cell proliferation, differentiation and apoptosis, as well as coagulation and lipid metabolism. TNF- $\alpha$ may decrease the appetite, body weight and body mass index (BMI), and induce the synthesis of catabolic hormones, including insulin-like growth hormone-1, and increase lipolysis in adipose tissue (13). As adipocytes have been recognized to actively participate in systemic immune responses via the secretion of peptides detectable in the systemic circulation, the so-called adipocytokines (adipokines) (14-16), increased lipolysis by increased TNF- $\alpha$ production results in impaired production of certain adipokines, such as leptin (13). In metabolism, the plasma levels of leptin serve as a signal of energy sufficiency to the hypothalamus, resulting in anorexia and increased energy expenditure when fat stores are exceeded (17). During inflammation, leptin may falsely signal an excess of fat mass to the hypothalamus and drive an inappropriate physiological response. In addition, if the TNF- $\alpha$ concentration diminishes when the immunologic response and inflammation decrease due to treatment with anti-TNF- $\alpha$ drugs, including infliximab (17-19), the deregulation of leptin by the use of biological therapy may be expected. Therefore, the regulation of leptin and other adipokines and its physiological consequences have been examined in human inflammatory diseases, including IBD (19-21). In one of these studies, Waluga et al (21), investigated serum adipokine levels (transforming growth factor- $\beta 1$, adiponectin, leptin, chemerin, resistin and visfatin) in patients with IBD prior treatment and after achieving clinical remission. Their results suggested that IBD modulated serum adipokine levels by increasing resistin and visfatin release and suppressing leptin production. These authors proposed leptin concentrations in CD and UC subjects, may be the result of TNF- $\alpha$ hyperactivity leading to a decrease in leptin mediated chronic inflammation. Accordingly, the aim of the present study was to evaluate the serum levels of 10 adipokines and their association with disease activity on endoscopy in IBD. The modulation of the adipokines by IBD therapy was also evaluated.

\section{Materials and methods}

Participants and biological samples. A case-control study consisting of non-related subjects from the Zacatecas state in Mexico was performed. Subjects were recruited from the Gastroenterological service of the Zacatecas Instituto de Seguridad y Servicios Sociales de los Trabajadores del Estado (ISSSTE) General Hospital (Zacatecas, Mexico) between July and October 2016. The protocol was approved by the Committee on Education, Research, Training and Ethics of ISSSTE General Hospital (approval ID, OFC226/2016-2-001). All participants provided written informed consent for their participation in the study, in accordance with the Helsinki declaration. IBD was diagnosed according to clinical, endoscopic and pathological criteria as previously described (18). All patients with previous diagnoses of IBD were included in the case group ( $n=34 ; \mathrm{UC}, \mathrm{n}=23 ; \mathrm{CD}, \mathrm{n}=11)$. All the cases at the time of recruitment had already received pharmacological therapy according with the World Gastroenterology Organization Global guidelines (22). The control group $(n=19)$ consisted of healthy subjects who were screened due to indications of colon cancer in accordance with the World Gastroenterology Organization guidelines (23) and absence of treatment with anti-inflammatory drugs. In the two groups, participants with comorbidities, including diabetes or autoimmune diseases, or with any associated inflammatory or infectious diseases, including tuberculosis, cytomegalovirus infection or urinary tract infection, were excluded.

Each of the participants donated a blood sample at the moment of their recruitment. Subsequently, they underwent a colonoscopy procedure according the guidelines of the American Society for Gastrointestinal Endoscopy (24). Tissue samples from colon segments were obtained for histopathologic evaluation using Multibite ${ }^{\mathrm{TM}}$ biopsy forceps (Boston Scientific, Boston, MA, USA) (24). Blood samples were centrifuged at $1,000 \mathrm{xg}$ for $15 \mathrm{~min}$ at room temperature (RT). Serum was collected, aliquoted and stored at $-80^{\circ} \mathrm{C}$ until use. Epidemiological and clinical data, including clinical activity/disease activity on endoscopy by appropriate scales [UC Mayo endoscopic score (UC-MES), UC endoscopic index of severity (UCEIS), UC/CD Montreal classification, CD activity index (CDAI), simple endoscopic scale for CD (SES-CD) and Truelove-Witts score] $(25,26)$, date of diagnosis, initial and current treatment, phenotype, extraintestinal manifestations of the disease and laboratory parameters, were obtained from clinical records. The presence of endoscopic activity for each IBD subtype was defined as the UC-MES and the UCEIS suggesting at least the mild stage for UC, and at least score 1 of the SES-CD and B2 of the Montreal classification for $\mathrm{CD}$. The size of mucosal ulcers, ulcerated surface, endoscopic extension and stenosis features were evaluated.

Marker quantification. The levels of 10 biomarkers, C-peptide, ghrelin, gastric inhibitory polypeptide (GIP), glucagon-like peptide-1 (GLP), glucagon (GCG), insulin (INS), leptin (LEP), total plasminogen activator inhibitor-1 (PAI-1), resistin (RETN) and visfatin, were analyzed using the Bio-Plex Pro Human Diabetes 10-Plex Panel (Bio-Rad Laboratories, Hercules, CA, USA). Serum quantification was performed as follows: Samples (aliquots of $200 \mu \mathrm{l}$ ) were centrifuged at $30,000 \mathrm{x}$ g for 
$5 \mathrm{~min}$ at RT to remove any precipitate. The appropriate analyte standards and samples were diluted in standard diluent and sample diluent, respectively. A standard curve composed of eight points was prepared from the recombinant analyte standard. Standards, blanks and samples were added to a 96-well plate containing antibodies that were chemically attached to fluorescent-labeled microbeads. The samples were incubated in the dark at room temperature in constant motion for $1 \mathrm{~h}$. The plate was washed three times, a detection antibody was added to each well, and the plate was incubated in the dark for $30 \mathrm{~min}$ at RT with agitation, followed by three washes. Streptavidin-phycoerythrin was added to each well and the plate was incubated in the dark for $10 \mathrm{~min}$ at RT with agitation. The beads were re-suspended in $125 \mu \mathrm{l}$ buffer, and the reaction was quantified using the BioPlex ${ }^{\circledR} 200$ Multiplex System platform (Bio-Rad Laboratories). Each sample was analyzed in duplicate and the data were automatically analyzed and processed using Bio-Plex Manager 6.1 software (Bio-Rad Laboratories).

Statistical analysis. Risk factors and clinical and personal characteristics were compared using a Chi-square or Fisher's exact test for categorical variables, and a Student's t-test, Mann-Whitney U test or analysis of variance (ANOVA) as appropriate, for numerical variables. ANOVA was coupled to Holm-Sidak or Dunn's Method as appropriate for the multiple comparison procedure. The usefulness of serum leptin levels to correctly classify the study groups according to their disease status was evaluated using a receiver operating characteristic curve (ROC) analysis. In this analysis, leptin sensitivity and specificity values were used to calculate the related area under the curve and the positive and negative predictive values at fixed protein concentration cutoffs. Each cutoff value for serum leptin level was obtained considering the ROC curve in which the value of the sum of sensitivity and specificity was maximal (sensitivity + specificity closest to two). The odds ratios with Yates continuity correction were calculated for significant comparisons. To evaluate the correlation between two variables, a Spearman Rank Order Correlation test was performed. $\mathrm{P}<0.05$ was considered to indicate a statistically significant difference. Data analysis was performed using Sigma Plot v.11 (Systat Software Inc., San Jose, CA, USA) and GraphPad Prism v.5.03 (GraphPad Software, Inc., La Jolla, CA, USA).

\section{Results}

Patient characteristics. A total of 53 participants were enrolled in the present study, including 34 patients diagnosed with IBD (UC, 23; CD, 11) and 19 healthy controls. General data and clinical characteristics of the study population are listed in Tables I and II. The median of age was 59 years (range, 26-78) for the cases and 54 (range, 31-49) years for the controls $(\mathrm{P}=0.312)$. There were no differences between the study groups in terms of risk factors and/or clinical variables, including gender, family history of IBD, smoking, BMI, hemoglobin, glucose, triglycerides, total cholesterol, high-density lipoprotein (HDL), low-density lipoprotein (LDL), very LDL (VLDL) or systolic/diastolic blood pressure $(\mathrm{P}>0.05)$.

$I B D$ and endoscopic activity. In the case group, the clinical activity in UC patients according to the Truelove-Witts scale
Table I. Classification of patients with inflammatory bowel disease $(n=34)$.

\begin{tabular}{|c|c|}
\hline Item & $\mathrm{N}(\%)$ \\
\hline \multicolumn{2}{|l|}{ Diagnosis } \\
\hline $\mathrm{UC}$ & $23(67.6)$ \\
\hline $\mathrm{CD}$ & $11(32.4)$ \\
\hline \multicolumn{2}{|c|}{ Mayo endoscopic activity } \\
\hline Remission & $8(23.5)$ \\
\hline Mild & $14(41.2)$ \\
\hline Moderate & $1(2.9)$ \\
\hline Severe & $0(0)$ \\
\hline \multicolumn{2}{|l|}{ Montreal UC } \\
\hline E1 & $7(20.6)$ \\
\hline E2 & $8(23.5)$ \\
\hline E3 & $8(23.5)$ \\
\hline \multicolumn{2}{|l|}{ UCEIS } \\
\hline Remission & $8(23.5)$ \\
\hline Mild & $14(41.2)$ \\
\hline Moderate & $1(2.9)$ \\
\hline Severe & $0(0)$ \\
\hline \multicolumn{2}{|c|}{ Truelove-witts clinical } \\
\hline Remission & $14(41.2)$ \\
\hline Mild & $6(17.6)$ \\
\hline Moderate & $3(8.8)$ \\
\hline Severe & $0(0)$ \\
\hline \multicolumn{2}{|l|}{ CDAI } \\
\hline$<150$ & $11(32.4)$ \\
\hline $150-220$ & $0(0)$ \\
\hline $220-450$ & $0(0)$ \\
\hline$>450$ & $0(0)$ \\
\hline \multicolumn{2}{|l|}{ Montreal CD } \\
\hline \multicolumn{2}{|l|}{ Location } \\
\hline SB & $3(8.8)$ \\
\hline Colon & $4(11.8)$ \\
\hline SB-colon & $4(11.8)$ \\
\hline Upper GI & $0(0)$ \\
\hline \multicolumn{2}{|l|}{ Behavior } \\
\hline Inflammatory & $6(17.6)$ \\
\hline Stricturing & $2(5.9)$ \\
\hline Fistulizing & $3(8.8)$ \\
\hline \multicolumn{2}{|c|}{ Endoscopy simple CD score } \\
\hline 0 & $5(14.7)$ \\
\hline 1 & $5(14.7)$ \\
\hline 2 & $1(2.9)$ \\
\hline 3 & $0(0)$ \\
\hline
\end{tabular}

UC, ulcerative colitis; CD, Crohn's disease; E, extension; UCEIS, ulcerative colitis endoscopic index of severity; CDAI, Crohn's disease activity index; GI, gastro-intestinal; SB, small bowel.

was as follows: 14 patients were in remission, 6 had mild activity and 3 had moderate activity. In the group of $\mathrm{CD}$ patients, the 
Table II. Comparison of clinical parameters between the study groups.

\begin{tabular}{|c|c|c|c|}
\hline Characteristic & IBD $(n=34)$ & Control $(n=19)$ & P-value \\
\hline Age (years) & $54.8 \pm 15.1$ & $53.2 \pm 9.6$ & 0.312 \\
\hline Gender (female/male ratio) & 1.43 & 5.3 & 0.111 \\
\hline Family history of IBD & $1(2.9 \%)$ & $1(5.2 \%)$ & 1.000 \\
\hline HDL (mg/dl) & $45.2 \pm 12.3$ & $45.7 \pm 12.5$ & 0.905 \\
\hline $\mathrm{LDL}(\mathrm{mg} / \mathrm{dl})$ & $110.5 \pm 27.6$ & $123.2 \pm 32.7$ & 0.155 \\
\hline VLDL (mg/dl) & $25.7 \pm 10.8$ & $23.2 \pm 6.5$ & 0.37 \\
\hline Triglycerides (mg/dl) & $131.7 \pm 51.5$ & $120.9 \pm 38.3$ & 0.446 \\
\hline Cholesterol (mg/dl) & $181.0 \pm 28.6$ & $191.6 \pm 41.3$ & 0.288 \\
\hline TIA (mg/dl) & $4.0 \pm 1.1$ & $4.3 \pm 1.1$ & 0.374 \\
\hline Glucose (mg/dl) & $90.2 \pm 20.2$ & $87.7 \pm 7.7$ & 0.953 \\
\hline Hemoglobin (g/dl) & $14.6 \pm 1.9$ & $14.1 \pm 1.8$ & 0.293 \\
\hline Hematocrit (\%) & $44.2 \pm 9.5$ & $41.0 \pm 4.3$ & 0.108 \\
\hline $\operatorname{BMI}\left(\mathrm{kg} / \mathrm{m}^{2}\right)$ & $27.6 \pm 5.9$ & $28.4 \pm 6.5$ & 0.711 \\
\hline $\mathrm{SBP}(\mathrm{mm} / \mathrm{Hg})$ & $114.1 \pm 9.8$ & $110.0 \pm 5.8$ & 0.228 \\
\hline $\mathrm{DBP}(\mathrm{mm} / \mathrm{Hg})$ & $77.2 \pm 5.8$ & $75.4 \pm 6.6$ & 0.315 \\
\hline $\operatorname{ESR}(\mathrm{mm} / \mathrm{h})$ & $1.5 \pm 0.51$ & $1.3 \pm 0.49$ & 0.322 \\
\hline CRP (mg/l) & $0.51 \pm 0.63$ & $0.35 \pm 0.29$ & 0.888 \\
\hline
\end{tabular}

Values are expressed as the mean \pm standard deviation, $\mathrm{n}(\%)$ or ratio. HDL, high-density lipoprotein; VLDL, very low-density lipoprotein; TIA, transient ischemic attack; BMI, body mass index; SBP, systolic blood pressure; DBP, diastolic blood pressure; ESR, erythrocyte sedimentation rate; CRP, C-reactive protein; IBD, inflammatory bowel disease.

Table III. Serum concentrations of the ten proteins evaluated in the IBD and control groups.

\begin{tabular}{lccc}
\hline Analyte & IBD $(\mathrm{n}=34)$ & Control $(\mathrm{n}=19)$ & P-value \\
\hline C-peptide $(\mathrm{pg} / \mathrm{ml})$ & $972.3 \pm 512.2$ & $975.4 \pm 281.0$ & 0.414 \\
Ghrelin $(\mathrm{pg} / \mathrm{ml})$ & $3,781.5 \pm 1,498.4$ & $3,471.4 \pm 878.9$ & 0.781 \\
GIP $(\mathrm{pg} / \mathrm{ml})$ & $524.9 \pm 381.9$ & $426.4 \pm 197.6$ & 0.549 \\
GLP-1 $(\mathrm{pg} / \mathrm{ml})$ & $834.9 \pm 126.9$ & $817.5 \pm 46.7$ & 0.838 \\
Glucagon $(\mathrm{pg} / \mathrm{ml})$ & $1,155.4 \pm 118.9$ & $1,119.4 \pm 64.9$ & 0.182 \\
Insulin $(\mathrm{pg} / \mathrm{ml})$ & $961.8 \pm 306.6$ & $911.8 \pm 236.1$ & 0.656 \\
Leptin $(\mathrm{pg} / \mathrm{ml})$ & $5,039.2 \pm 5,219.8$ & $8,847.6 \pm 4,044.2$ & $4.9 \times 10^{-4 a}$ \\
PAI-1 $(\mathrm{pg} / \mathrm{ml})$ & $78,984.5 \pm 58,986.9$ & $82,870.7 \pm 38,624.1$ & 0.541 \\
Resistin $(\mathrm{pg} / \mathrm{ml})$ & $4,491.8 \pm 1,984.1$ & $5,131.0 \pm 3,061.5$ & 0.738 \\
Visfatin $(\mathrm{pg} / \mathrm{ml})$ & $11,622.4 \pm 3,6291.3$ & $4,494.1 \pm 883.1$ & 0.656 \\
\hline
\end{tabular}

${ }^{\mathrm{a}} \mathrm{P}<0.05$. Serum levels of the proteins were determined at baseline. Values are expressed as the mean \pm standard deviation. IBD, inflammatory bowel disease; GIP, gastric inhibitory polypeptide; GLP, glucagon-like peptide-1, PAI-1, total plasminogen activator inhibitor-1.

clinical activity was determined as $<150$ points on the CDAI scale. In the UC group, maximal endoscopic involvement (E1) was observed in 7 cases, E2 was observed in 8 subjects and the E3 stage was observed in the remaining 8 UC cases. The location of CD according to the Montreal classification was in the small bowel for 3 participants, in the colon for 4 cases and in the colonic ileum for the remaining $4 \mathrm{CD}$ cases. Evaluation of the endoscopic activity of UC according to the UC-MES indicated that 8 cases were in remission, 14 had mild activity and one had moderate endoscopic activity. In CD patients, no endoscopic activity (SES-CD score=0) was observed in
5 patients, while 5 and 1 patients displayed activity with score of 1 and 2, respectively (Table I). Extraintestinal manifestations were observed in 4 UC cases $(27.3 \%)$ and in 3 CD cases (17.4\%), respectively.

Leptin levels are associated with IBD. Table III displays the results of the adipokine quantification determined at baseline in the serum of IBD patients and control subjects. Of note, the serum levels of leptin in the IBD group were significantly lower than those in the controls $(5,039.2 \pm 5,219.8$ vs. $\left.8,847.6 \pm 4,044.2 \mathrm{pg} / \mathrm{ml} ; \mathrm{P}=4.9 \times 10^{-4}\right)$. However, there 
Table IV. Comparison of serum adipokine levels between the study groups.

\begin{tabular}{|c|c|c|c|c|}
\hline Analyte & Control (n=19) & $\mathrm{CD}(\mathrm{n}=11)$ & $\mathrm{UC}(\mathrm{n}=23)$ & P-value \\
\hline C peptide (pg/ml) & $975.4 \pm 281.0$ & $1,112.6 \pm 468.2$ & $905.19 \pm 528.5$ & 0.208 \\
\hline Ghrelin (pg/ml) & $3,471.4 \pm 878.9$ & $4,192.5 \pm 1,929.8$ & $3,584.94 \pm 1,245.1$ & 0.745 \\
\hline GIP (pg/ml) & $426.4 \pm 197.6$ & $635.3 \pm 506.2$ & $469.7 \pm 301.1$ & 0.150 \\
\hline GLP-1 (pg/ml) & $817.5 \pm 46.7$ & $860.4 \pm 133.0$ & $822.71 \pm 125.0$ & 0.292 \\
\hline Glucagon (pg/ml) & $1,119.4 \pm 64.9$ & $1,184.7 \pm 163.7$ & $1,141.4 \pm 91.5$ & 0.251 \\
\hline Insulin (pg/ml) & $911.8 \pm 236.1$ & $1,052.0 \pm 291.4$ & $918.68 \pm 310.5$ & 0.176 \\
\hline Leptin (pg/ml) & $8,847.6 \pm 4,044.22$ & $7,257.4 \pm 8,051.3$ & $3,978.26 \pm 2,787.0$ & $0.001^{\mathrm{a}}$ \\
\hline PAI-1 (pg/ml) & $82,870.7 \pm 38,624.1$ & $109,456.2 \pm 93,303.5$ & $64,411 \pm 23,996.3$ & 0.090 \\
\hline Resistin (pg/ml) & $5,131.0 \pm 3,061.5$ & $5,189.8 \pm 2,282.6$ & $41,58.01 \pm 1,782.3$ & 0.457 \\
\hline Visfatin (pg/ml) & $4,494.1 \pm 883.2$ & $6,230.6 \pm 6,232.3$ & $14,201.0 \pm 44,005$ & 0.745 \\
\hline
\end{tabular}

${ }^{\mathrm{a}} \mathrm{P}<0.05$ Control vs. UC vs. CD (analysis of variance test). Serum levels of the proteins were determined at baseline. Values are expressed as the mean \pm standard deviation. IBD, inflammatory bowel disease; GIP, gastric inhibitory polypeptide; GLP, glucagon-like peptide-1; PAI-1, total plasminogen activator inhibitor-1; UC, ulcerative colitis; CD, Crohn's disease.

were no significant differences in the serum levels of the 9 remaining adipokines $(\mathrm{P}>0.05)$.

When the IBD participants were stratified into UC and CD groups (Table IV), the serum levels of leptin in UC patients were significantly lower than those in $\mathrm{CD}$ patients $(\mathrm{P}=0.001)$. Leptin serum levels did not significantly differ between UC and $C D$ groups $(P>0.05)$. No differences in the serum levels of the other adipokines were identified between the UC, CD and healthy controls groups.

Leptin levels are associated with endoscopic activity in IBD patients. Leptin serum concentrations were determined at baseline and as presented in Fig. 1, the leptin levels were compared between patient groups stratified by the presence/absence of disease activity on endoscopy. Compared with the control group, IBD patients with and without disease activity on endoscopy had lower serum leptin levels $(\mathrm{P}<0.001)$. In CD (Fig. 1B) and UC patients (Fig. 1C), significant differences in serum leptin levels were observed between controls and patients with and without disease activity on endoscopy $(\mathrm{P}=0.001)$. Compared with those in the controls and IBD without disease activity on endoscopy, the serum leptin levels in IBD patients with positive endoscopic activity was significantly lower $(\mathrm{P}<0.001$; data not shown).

To determine whether the circulating leptin concentration was affected by IBD treatment, IBD cases were stratified according to their pharmacological therapy, and the leptin levels were compared between the groups (Fig. 2A; Table V). Compared with the controls, serum leptin levels were reduced in patients treated with 5-aminosalicylic acid (5-ASA) monotherapy $(\mathrm{P}=0.008), 5-\mathrm{ASA}+$ azathioprine $(\mathrm{P}=0.002)$ and 5-ASA + adalimumab $(\mathrm{P}=0.036)$. IBD participants then evaluated separately as CD (Fig. 2B) or UC groups (Fig. 2C). Compared with the controls, the serum leptin levels were significantly lower in UC patients with 5-ASA monotherapy $(\mathrm{P}=0.0015)$ and 5 -ASA + azathioprine $(\mathrm{P}=0.002)$, but not in those with 5-ASA + adalimumab $(\mathrm{P}=0.165)$. Leptin levels in $\mathrm{CD}$ patients receiving various treatments were not significantly
Table V. General description of the treatment of patients with inflammatory bowel disease.

\begin{tabular}{lcc}
\hline Treatment/item & $\begin{array}{c}\text { Ulcerative } \\
\text { colitis }\end{array}$ & $\begin{array}{c}\text { Crohn's } \\
\text { disease }\end{array}$ \\
\hline Current treatment & 15 & 2 \\
5-ASA & 5 & 7 \\
5-ASA + Azathioprine & 3 & 2 \\
5-ASA + Adalimumab & & \\
Use of anti-TNF- $\alpha$ in the & 5 & 2 \\
course of the disease & 15 & 7 \\
Yes & & \\
No & 3 & 2 \\
Change in anti-TNF- $\alpha$ regimen & 2 & 1 \\
Maintenance treatment & 1 & 0 \\
Failure & 2 & 0 \\
Allergic reaction & 0 & 1 \\
Restart treatment due to relapse & & \\
Azathioprine intolerance &
\end{tabular}

5-ASA, 5-aminosalicylic acid; TNF, tumor necrosis factor.

different from those in healthy controls $(\mathrm{P}>0.05)$. In the same sense, additional differences between pairs of treatments were not found with or without stratification of the IBD participants $(\mathrm{P}>0.05)$.

Association of leptin with the location of IBD. Regarding the location of IBD, leptin levels were significantly decreased in UC patients with right colitis $\left(\mathrm{P}=4.95 \times 10^{-7}\right)$ and pancolitis $(\mathrm{P}=0.001)$ compared with those in the controls. In the CD group, a significant reduction of the leptin concentration was observed in patients with disease located in the colonic ileum compared with that in the control group $(\mathrm{P}=0.001$; Fig. 3$)$. Significant differences in leptin levels between right colitis 

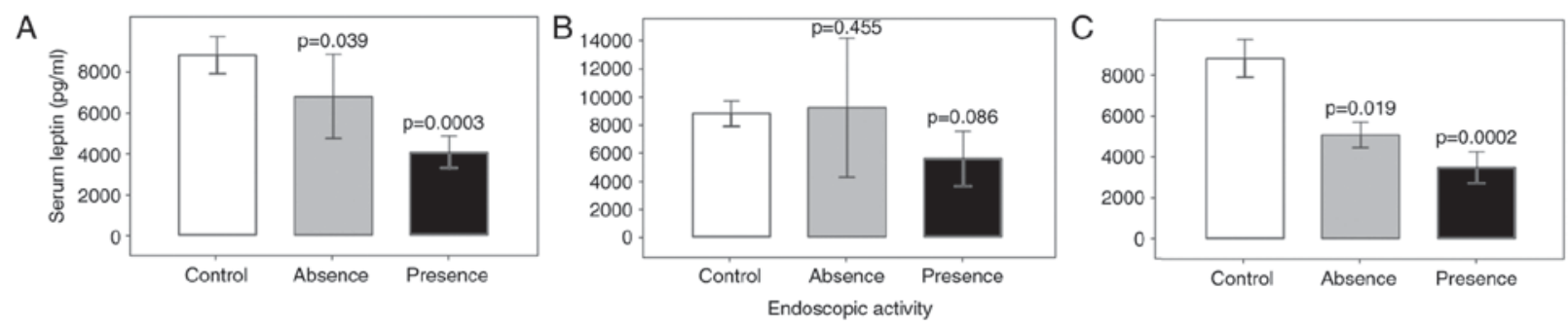

Figure 1. Serum concentrations of leptin and disease activity in groups with and without endoscopic activity. Leptin levels were determined at baseline and using the healthy control group as a reference, the serum leptin concentration $(\mathrm{pg} / \mathrm{ml})$ was compared between the patients with and without endoscopic activity in the (A) inflammatory bowel disease (B) Crohn's disease and (C) ulcerative colitis groups. Values are expressed as the mean \pm standard deviation from duplicate readings.
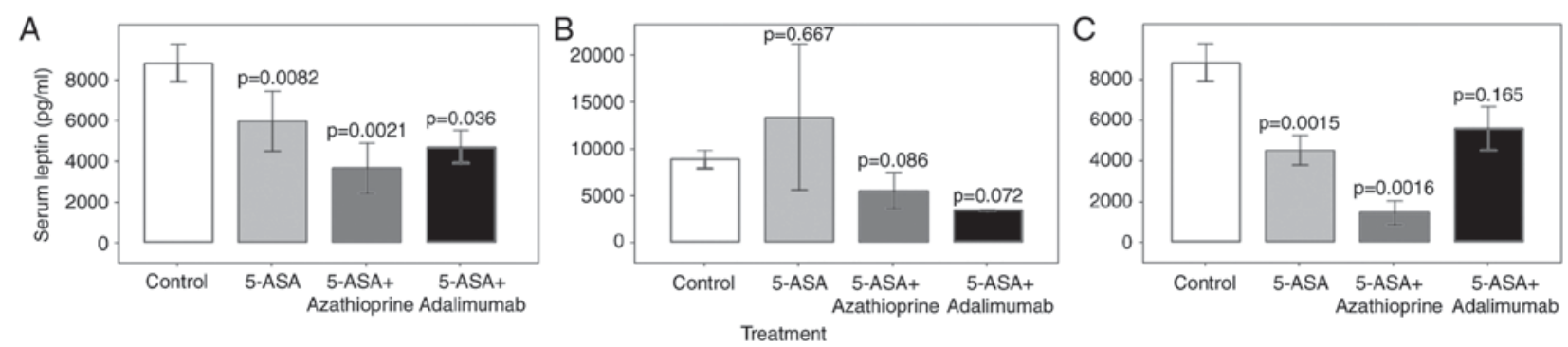

Figure 2. Modulation of the serum concentration of leptin with treatment. The IBD patients were stratified into 5-ASA, 5-ASA+azathioprine and 5-ASA+adalimumab groups according to their pharmacological therapy. The serum levels of leptin ( $\mathrm{pg} / \mathrm{ml}$ ) in the (A) IBD, (B) Crohn's disease and (C) ulcerative colitis patients were compared with those in the control group as a reference. Values are expressed as the mean \pm standard deviation from duplicate readings. IBD, inflammatory bowel disease; ASA, 5-aminosalicylic acid.
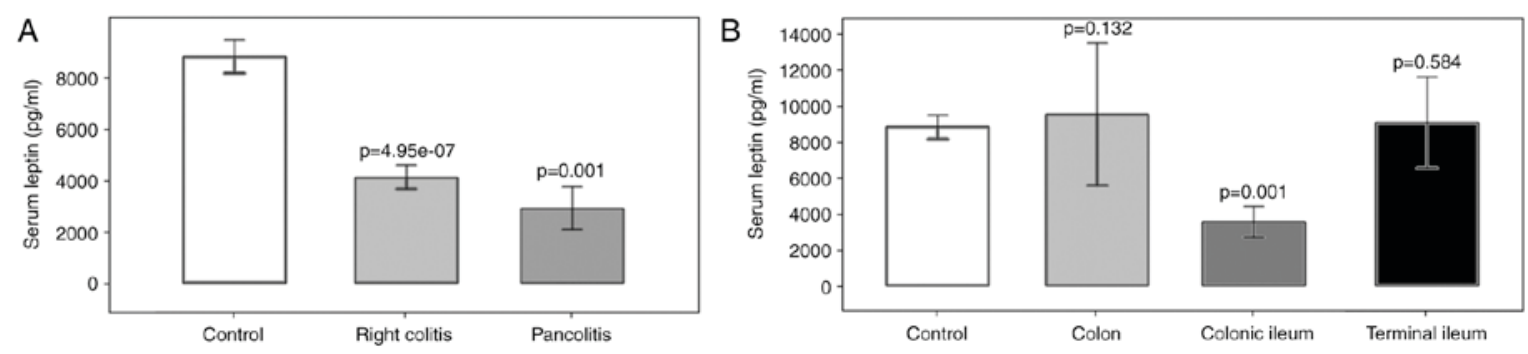

Figure 3. Association of serum leptin concentration with the extent of the disease. (A) Comparison of serum leptin concentration (pg/ml) with extent of disease in UC patients. UC patients were classified into right colitis and pancolitis groups and compared with the healthy control group. (B) Comparison of serum leptin concentration $(\mathrm{pg} / \mathrm{ml})$ with extent of disease in $\mathrm{CD}$ patients. CD patients were classified into colon, colonic ileum and terminal ileum and compared with the healthy control group. Values are expressed as the mean \pm standard deviation from duplicate readings. UC, ulcerative colitis; $\mathrm{CD}$, Crohn's disease.

and pancolitis, or colon, colonic ileum or terminal ileum were not identified $(\mathrm{P}>0.05)$.

Regarding the presence/absence of an extraintestinal manifestation of IBD as a classifier and using the control group as a reference, circulating leptin was lower in patients without extraintestinal manifestations $(6,404.4 \pm 5,133.4 \mathrm{pg} / \mathrm{ml}$; $\mathrm{P}=0.002)$. No significant differences were observed in serum leptin levels between controls and IBD cases with extraintestinal manifestations $(\mathrm{P}=0.053)$, or between IBD cases with or without extraintestinal manifestations $(\mathrm{P}=0.848)$. The serum levels of the 9 remaining markers evaluated were not affected by the presence of extraintestinal manifestations (data not shown).

Correlation of leptin with clinical parameters. To evaluate the correlation between leptin levels and clinical features of the study population, a correlation analysis was performed. A positive correlation was identified between serum leptin levels and BMI $(\mathrm{r}=+0.35, \mathrm{P}=0.017)$, while a negative correlation between serum leptin levels and hemoglobin was observed $(\mathrm{r}=-0.31, \mathrm{P}=0.026)$. No significant correlation between leptin levels and other clinical parameters, including C-reactive protein (CRP) or the erythrocyte sedimentation rate (ESR), were identified $(\mathrm{P}>0.05)$.

Circulating leptin as a marker for IBD and endoscopic activity. To evaluate the usefulness of serum leptin levels to correctly classify the study groups according to their disease status, a receiver operating characteristic (ROC) analysis was performed (Table VI). Regarding the use of serum leptin for the diagnosis of IBD with a cutoff value of $5,494 \mathrm{pg} / \mathrm{ml}$, the sensitivity and specificity values were calculated as 71 and $84 \%$, respectively. Serum leptin levels $<5,494 \mathrm{pg} / \mathrm{ml}$ significantly increased the odds of IBD by 12.8 -fold among the study population [odds ratio $(\mathrm{OR})=12.8,95 \%$ confidence interval $(\mathrm{CI})=3.04-53.9$, 
Table VI. ROC analysis of serum leptin in IBD patients.

\begin{tabular}{lcc}
\hline Parameter & IBD vs. controls & Endoscopic activity (presence vs. absence) \\
\hline Area under ROC curve & 0.791 & 0.651 \\
Leptin cutoff (pg/ml) & 5,494 & 2,498 \\
Sensitivity (\%) & 71 & 45 \\
Specificity (\%) & 84 & 88 \\
Predictive positive value (\%) & 89 & 87 \\
Predictive negative value (\%) & 38 & 1 \\
Odds ratio & 12.8 & 5.8 \\
95\% Confidence interval & $3.04-53.9$ & $1.52-22.4$ \\
P-value & $<0.001$ & 0.013
\end{tabular}

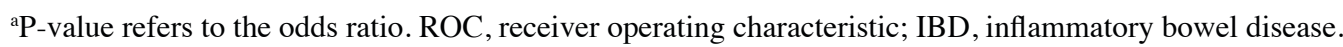

$\mathrm{P}=0.001]$. The odds of disease activity on endoscopy in patients with serum leptin levels of $<2,498 \mathrm{pg} / \mathrm{ml}$ was increased 5.8 -fold among the IBD patients $(\mathrm{OR}=5.8,95 \% \mathrm{CI}=1.52-22.4, \mathrm{P}=0.013)$.

\section{Discussion}

The traditional assessment of IBD patients is somewhat complicated by the necessary, but rather invasive nature of evaluation, including endoscopic procedures with biopsies (27). To date, no ideal biomarker has been identified for the assessment and management of IBD. The aim of the present study was to evaluate the serum levels of C-peptide, ghrelin, GIP, GLP, glucagon, insulin, leptin, PAI-1, resistin and visfatin and their association with endoscopic activity in IBD. These proteins are produced by white adipose tissue (WAT), which functions not only as a reservoir of free fatty acids (energy source) but also as an endocrine organ, sending out and responding to signals that modulate appetite, energy expenditure, insulin sensitivity, the endocrine and reproductive systems, bone metabolism and immunity. Accordingly, WAT and its signaling molecules provide an important link between obesity, insulin resistance and inflammatory disorders $(28,29)$. In the present study, among the 10 adipokines evaluated, leptin levels were significantly lower in patients with IBD compared with those in healthy controls. Leptin, a 16-kDa polypeptide encoded by the $o b$ gene, is mainly produced by adipocytes in adipose tissue, and at lower levels by fundic epithelium of peripheral tissues including that of the gastric mucosa, skeletal muscle, lymph node, liver, thyroid, placenta and spinal cord (30). The most important functions of leptin are inhibition of appetite and modulation of immune and inflammatory reactions. The results of the present study are in agreement with those reported by Waluga et al (21) from 2014 and Karmiris et al (31) from 2006, whose case-control studies indicated decreased serum leptin levels in subjects with the two types of IBD compared with those in healthy controls. However, in other previous studies, serum leptin levels were reported to increase $(32)$ or remain unchanged $(33,34)$ in IBD patients compared with those in healthy controls. Despite the discrepancy in serum leptin levels, an increase in leptin in close proximity to the site of inflammation has been consistently reported, with a significant increase in mRNA expression and secretion of leptin from mesenteric adipose tissue of CD and
UC patients compared with that in controls $(35,36)$. At the tissue level, where protein production reflects local cellular behavior, the circulating concentrations of molecules represent the total contribution of the body tissues and therefore, they are useful to identify additional changes associated with the general health state of the patient or with other external variables. As observed in the present study, leptin levels were associated with the BMI, the extent of the affected area, disease activity and/or treatment. Accordingly, the discrepancies observed in serum leptin concentrations between studies may be explained in part by the differences in those features between the populations evaluated.

In the present study, when the participants were stratified according to the presence/absence of endoscopic activity, the serum leptin levels in the group with disease activity on endoscopy were significantly decreased relative to those in the controls, as well as in patients with vs. without disease activity on endoscopy, suggesting the involvement of a defective regulation of the leptin pathway in the pathogenesis of IBD. When the IBD participants were stratified into CD and UC groups and compared with the controls, differences in serum leptin levels were observed for the UC group but not for the CD group, reflecting differences in the molecular mechanisms for the two types of IBD. Although these results should be validated in other IBD cohorts with large patient numbers, the present study obtained a 12.8-fold increased odds of IBD among the study population when a cutoff for serum leptin levels $<5,494 \mathrm{pg} / \mathrm{ml}$ was chosen. In addition, regarding the presence or absence of disease activity on endoscopy, serum leptin levels with cutoff $<2,498 \mathrm{pg} / \mathrm{ml}$ provided a 5.8 -fold increased odds of disease activity on endoscopy among the IBD patients, suggesting that the leptin concentration may represent an attractive marker to consider in IBD risk determination. It is important to note that in the study population, the known non-invasive biomarkers of IBD (CRP and ESR) had normal values in most of the participants, and therefore, its classifier value for disease activity on endoscopy was not comparable with that of leptin. Additional studies are therefore required to evaluate this comparison.

In the present study, a significant decrease in leptin levels was identified between the control and different treatment groups (5-ASA, 5-ASA + azathioprine, 5-ASA + adalimumab). Of note, when IBD patients were evaluated separately as CD or UC groups, differences in serum leptin levels compared 
with those in the control group were only observed in the UC group for the 5-ASA and 5-ASA + azathioprine, but not for the 5-ASA + adalimumab treatment, suggesting that the treatment with 5-ASA + adalimumab may partially restore the leptin levels in UC but no in CD patients. As the present study was a transversal case-control study and considering that the cohort did not include any IBD patients without treatment, additional studies are required to determine whether the downregulation of leptin in IBD patients compared with that in healthy controls was independent of the prescribed treatments. In this sense, Waluga et al (21) postulated that low leptin levels may be a result of TNF- $\alpha$ hyperactivity. As TNF- $\alpha$ stimulates the temporary release of substantial amounts of leptin in response to inflammation, a decrease in leptin-mediated chronic inflammation may eventually be expected. It has been demonstrated that serum leptin levels increased in CD subjects treated with the TNF- $\alpha$ antagonist infliximab, confirming the role of TNF- $\alpha$ in the regulation of leptin release by adipocytes (37). In addition, in the study by Waluga et al (21) reported that a 3-month treatment period with corticosteroids alone or with azathioprine lead to an increased plasma concentration of leptin in CD patients (21). Is important to mention that large errors values in the leptin serum levels were observed, mainly on the $\mathrm{CD}$ subjects, this may be due to the sample size and/or the differences in pharmacologic treatment initiation between patients. The large data dispersion may have an impact on the statistical analysis, and may therefore be considered a limitation of the present study.

Finally, the present study identified a significant positive correlation between leptin and BMI and a negative correlation between leptin and hemoglobin levels. A previous study indicated that leptin and erythropoietin acted synergistically to increase erythroid development in vitro (38). Although the effect of leptin on hematopoiesis may be modest, the present results are in accordance with that reported previously by Togo et al (39), whose identified a negative correlation between the levels of leptin and those of hemoglobin in Japanese men, suggesting that leptin may have a role in hematopoiesis in humans.

Although CD and UC have certain clinical and pathological features in common, they may be distinguished based on their localization, endoscopic appearance, histology and behavior, which suggests differences in the underlying pathophysiology. In accordance with the present results, these differences are also reflected in the circulating leptin levels, supporting the involvement of leptin in the pathogenesis of IBD, suggesting the suitability of leptin as a non-invasive marker to determine the risk of disease activity on endoscopy and its potential utility as a marker to optimize the treatment of UC.

In conclusion, the present study indicated that serum leptin is decreased in IBD. Low serum leptin levels were associated with an increased risk of IBD and disease activity on endoscopy among the study population. Additional studies are required to validate these results in populations with a greater number of IBD patients.

\section{Acknowledgements}

The authors would like to thank all of the study participants. The authors also appreciate contributions from Dr Adrian Lopez Saucedo and Dr Manuel Presno Bernal for their scientific advice and to Miss Alma Martinez for her assistance and technical support. The facilities for the development of the study provided by the Department of Education of the General Hospital of ISSSTE are also recognized. This work was funded in part by CONACYT (grant nos. CONACYT-S EP-CB-2009-01-0128567, -FOMIX-M0024-2013-01-203220, -SS/IMSS/ISSSTE-2010-138721, -SS/IMSS/ISSSTE2012-01-181124,-INFR-2014-225520, andINFR-2015-254106). The editing costs of the manuscript were covered in part by the Promotion of Quality Program (PFC) support (to the academic team with registration number: CA-UAZ-207).

\section{References}

1. Kuna AT: Serological markers of inflammatory bowel disease. Biochem Med (Zagreb) 23: 28-42, 2013.

2. Yamamoto-Furusho JK: Clinical epidemiology of ulcerative colitis in Mexico: A single hospital-based study in a 20-year period (1987-2006). J Clin Gastroenterol. 43: 221-224, 2009.

3. Cronica: In Mexico there was a triple increase in the number of cases of inflammatory bowel disease. http://www.cronica.com.mx/ notas/2017/1015339.html (In Spanish). Accessed July 21, 2017.

4. Cosnes J, Gower-Rousseau C, Seksik P and Cortot A: Epidemiology and natural history of inflammatory bowel diseases. Gastroenterology 140: 1785-1794, 2011.

5. Solberg IC, Lygren I,Jahnsen J, AadlandE,Høie O,Cvancarova M, Bernklev T, Henriksen M, Sauar J, Vatn MH, et al: Clinical course during the first 10 years of ulcerative colitis: Results from a population-based inception cohort (IBSEN Study). Scand J Gastroenterol 44: 431-440, 2009.

6. Sandborn WJ, Feagan BG, Hanauer SB, Lochs H, Löfberg R, Modigliani R, Present DH, Rutgeerts P, Schölmerich J, Stange EF and Sutherland LR: A review of activity indices and efficacy endpoints for clinical trials of medical therapy in adults with Crohn's disease. Gastroenterology 122: 512-530, 2002.

7. Stange EF, Travis SP, Vermeire S, Beglinger C, Kupcinkas L, Geboes K, Barakauskiene A, Villanacci V, Von Herbay A, Warren BF, et al: European evidence based consensus on the diagnosis and management of Crohn's disease: Definitions and diagnosis. Gut 1 (55 Suppl): i1-15, 2006.

8. Van Assche G, Dignass A, Panes J, Beaugerie L, Karagiannis J, Allez M, Ochsenkühn T, Orchard T, Rogler G, Louis E, et al: The second European evidence-based consensus on the diagnosis and management of Crohn's disease: Definitions and diagnosis. J Crohns Colitis 4: 7-27, 2010.

9. Colombel JF, Sandborn WJ, Reinisch W, Mantzaris GJ, Kornbluth A, Rachmilewitz D, Lichtiger S, D'Haens G, Diamond RH, Broussard DL, et al: Infliximab, azathioprine, or combination therapy for Crohn's disease. N Engl J Med 362: 1383-1395, 2010.

10. Beaugerie L, Brousse N, Bouvier AM, Colombel JF, Lémann M, Cosnes J, Hébuterne X, Cortot A, Bouhnik Y, Gendre JP, et al: Lymphoproliferative disorders in patients receiving thiopurines for inflammatory bowel disease: A prospective observational cohort study. Lancet 374: 1617-1625, 2009.

11. Peyrin-Biroulet L, Khosrotehrani K, Carrat F, Bouvier AM, Chevaux JB, Simon T, Carbonnel F, Colombel JF, Dupas JL, Godeberge $\mathrm{P}$, et al: Increased risk for nonmelanoma skin cancers in patients who receive thiopurines for inflammatory bowel disease. Gastroenterology 141: 1621-1628.e1-5, 2011.

12. Beaugerie L and Sokol H: Clinical, serological and genetic predictors of inflammatory bowel disease course. World J Gastroenterol 18: 3806-3813, 2012.

13. Ehsani AH, Mortazavi H, Balighi K, Hosseini MS, Azizpour A, Hejazi SP, Goodarzi A and Darvari SB: Changes in body mass index and lipid profile in psoriatic patients after treatment with standard protocol of infliximab. Acta Med Iran 54: 570-575, 2016.

14. Kopp A, Buechler C, Neumeier M, Weigert J, Aslanidis C, Schölmerich $\mathrm{J}$ and Schäffler A: Innate immunity and adipocyte function: Ligand-specific activation of multiple Toll-like receptors modulates cytokine, adipokine, and chemokine secretion in adipocytes. Obesity (Silver Spring) 17: 648-656, 2009.

15. Schäffler A, Schölmerich J and Salzberger B: Adipose tissue as an immunological organ: Toll-like receptors, C1q/TNFs and CTRPs. Trends Immunol 28: 393-399, 2007. 
16. Schäffler A and Buechler C: CTRP family: Linking immunity to metabolism. Trends Endocrinol Metab 23: 194-204, 2012.

17. Friedman JM and Halaas JL: Leptin and the regulation of body weight in mammals. Nature 395: 763-770, 1998.

18. Lennard-Jones JE: Classification of inflammatory bowel disease Scand J Gastroenterol Suppl 170: 2-6; discussion 16-19, 1989.

19. Bruun JM, Pedersen SB, Kristensen K and Richelsen B: Effects of pro-inflammatory cytokines and chemokines on leptin production in human adipose tissue in vitro. Mol Cell Endocrinol 190: 91-99, 2002.

20. Kirchgessner TG, Uysal KT, Wiesbrock SM, Marino MW and Hotamisligil GS: Tumor necrosis factor-alpha contributes to obesity-related hyperleptinemia by regulating leptin release from adipocytes. J Clin Invest 100: 2777-2782, 1997.

21. Waluga $M$, Hartleb $M$, Boryczka G, Kukla $M$ and Zwirska-Korczala K: Serum adipokines in inflammatory bowel disease. World J Gastroenterol 20: 6912-6917, 2014.

22. Bernstein CN, Eliakim A, Fedail S, Fried M, Gearry R, Goh KL, Hamid S, Khan AG, Khalif I, Ng SC, et al: World gastroenterology organisation global guidelines inflammatory bowel disease: Update August 2015. J Clin Gastroenterol 50: 803-818, 2016.

23. Winawer SJ, Krabshuis J, Lambert R, O'Brien M and Fried M; World Gastroenterology Organization Guidelines Committee Cascade colorectal cancer screening guidelines: A global conceptual model. J Clin Gastroenterol 45: 297-300, 2011.

24. American Society for Gastrointestinal Endoscopy Standards of Practice Committee, Shergill AK, Lightdale JR, Bruining DH, Acosta RD, Chandrasekhara V, Chathadi KV, Decker GA, Early DS, Evans JA, et al: The role of endoscopy in inflammatory bowel disease. Gastrointest Endosc 81: 1101-1121.e1-13, 2015.

25. Travis SP, Schnell D, Krzeski P, Abreu MT, Altman DG, Colombel JF, Feagan BG, Hanauer SB, Lémann M, Lichtenstein GR, et al: Developing an instrument to assess the endoscopic severity of ulcerative colitis: The Ulcerative colitis endoscopic index of severity (UCEIS). Gut 61: 535-542, 2012.

26. D'Haens G, Sandborn WJ, Feagan BG, Geboes K, Hanauer SB Irvine EJ, Lémann M, Marteau P, Rutgeerts P, Schölmerich J and Sutherland LR: A review of activity indices and efficacy end points for clinical trials of medical therapy in adults with ulcerative colitis. Gastroenterology 132: 763-786, 2007.

27. Barnes EL and Burakoff R: New biomarkers for diagnosing inflammatory bowel disease and assessing treatment outcomes. Inflamm Bowel Dis 22: 2956-2965, 2016.

28. Wang P, Mariman E, Renes J and Keijer J: The secretory function of adipocytes in the physiology of white adipose tissue. J Cell Physiol 216: 3-13, 2008.
29. Bastard JP, Maachi M, Lagathu C, Kim MJ, Caron M, Vidal H, Capeau $J$ and Feve B: Recent advances in the relationship between obesity, inflammation, and insulin resistance. Eur Cytokine Netw 17: 4-12, 2006

30. Sobhani I, Bado A, Vissuzaine C, Buyse M, Kermorgant S, Laigneau JP, Attoub S, Lehy T, Henin D, Mignon M and Lewin MJ: Leptin secretion and leptin receptor in the human stomach. Gut 47: 178-183, 2000.

31. Karmiris K, Koutroubakis IE, Xidakis C, Polychronaki M, Voudouri T and Kouroumalis EA: Circulating levels of leptin, adiponectin, resistin, and ghrelin in inflammatory bowel disease. Inflamm Bowel Dis 12: 100-105, 2006.

32. Tuzun A, Uygun A, Yesilova Z, Ozel AM, Erdil A, Yaman H, Bagci S, Gulsen M, Karaeren N and Dagalp K: Leptin levels in the acute stage of ulcerative colitis. J Gastroenterol Hepatol 19: 429-432, 2004

33. Ballinger A, Kelly P, Hallyburton E, Besser R and Farthing M: Plasma leptin in chronic inflammatory bowel disease and HIV: Implications for the pathogenesis of anorexia and weight loss. Clin Sci (Lond) 94: 479-483, 1998.

34. Hoppin AG, Kaplan LM, Zurakowski D, Leichtner AM and Bousvaros A: Serum leptin in children and young adults with inflammatory bowel disease. J Pediatr Gastroenterol Nutr 26: 500-505, 1998

35. Barbier M, Vidal H, Desreumaux P, Dubuquoy L, Bourreille A, Colombel JF, Cherbut C and Galmiche JP: Overexpression of leptin mRNA in mesenteric adipose tissue in inflammatory bowel diseases. Gastroenterol Clin Biol 27: 987-991, 2003.

36. Paul G, Schäffler A, Neumeier M, Fürst A, Bataillle F, Buechler C, Müller-Ladner U, Schölmerich J, Rogler G and Herfarth H: Profiling adipocytokine secretion from creeping fat in Crohn's disease. Inflamm Bowel Dis 12: 471-477, 2006.

37. Franchimont D, Roland S, Gustot T, Quertinmont E, Toubouti Y, Gervy MC, Deviere J and Van Gossum A: Impact of infliximab on serum leptin levels in patients with Crohn's disease. J Clin Endocrinol Metab 90: 3510-3516, 2005.

38. Bennett BD, Solar GP, Yuan JQ, Mathias J, Thomas GR and Matthews W: A role for leptin and its cognate receptor in hematopoiesis. Curr Biol 6: 1170-1180, 1996.

39. Togo M, Tsukamoto K, Satoh H, Hara M, Futamura A, Nakarai H, Nakahara K and Hashimoto Y: Relationship between levels of leptin and hemoglobin in Japanese men. Blood 93: 4444-4445, 1999.

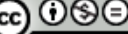

This work is licensed under a Creative Commons

Attribution-NonCommercial-NoDerivatives 4.0 International (CC BY-NC-ND 4.0) License. 